Selcuk Journal of Agriculture and Food Sciences

http://sjafs.selcuk.edu.tr/sjafs/index

Research Article

\section{SJAFS}

(2019) 33 (3), 227-230

e-ISSN: $2458-8377$

DOI:10.15316/SJAFS.2019.180

\title{
The Effect of Some Environmental Factors on Diurnial Distribution of Births in Anatolian Merino Sheep
}

\author{
Koray UĞUR ${ }^{1}$, Ali KARABACAK ${ }^{2, *}$ \\ ${ }^{1}$ Refahiye District Directorate of Agriculture and Forestry, Erzincan, Turkey \\ ${ }^{2}$ Selcuk University, Faculty of Agriculture, Department of Animal Science, Konya, Turkey
}

\begin{tabular}{l}
\hline ARTICLE INFO \\
\hline Article history: \\
Received date: 09.05 .2019 \\
Accepted date: 07.08 .2019 \\
\hline Edited by: \\
Ibrahim AYTEKIN; Selçuk University, \\
Turkey \\
Reviewed by: \\
Uğur ZÜLKADİ; Selçuk University, \\
Turkey \\
Nazan KOLUMAN; Çukurova \\
University, Turkey \\
\hline Keywords: \\
Anatolian Merino \\
Birth time \\
Sex \\
Birth type
\end{tabular}

\section{Introduction}

As in all animal reproduction areas, one of the most important issues in sheep breeding is fertility. Increasing fertility is possible by providing appropriate conditions as soon as possible after birth. The period up to several hours after the onset of travail is a period of intense stress for the mother and offspring and various complications. For this reason, it is important for the breeder to be aware of birth behaviors in terms of success in production, maintenance, and management related issues (Özçalık et al., 2012). Investigating animal behavior provides an understanding of the particular characteristics of an animal and how it reacts to the environment. Considering that the methods used in animal husbandry practices are developed depending on animal behavior, the importance of research on animal behavior is understood better. By having the animals adapt to the changes in the environmental conditions, their behavior can be directed accordingly. Therefore, in order to understand animal behavior,

\footnotetext{
*Corresponding author email: akarabacak@selcuk.edu.tr
}

environmental factors affecting behavior and behavioral function should be known well (Demirören, 2002).

Although a few hours at delivery and after birth is one of the important processes that affect the productivity of the farm in animal production, adequate information has not yet been obtained on birth and birth behaviors. Taking full advantage of reproductive performance affects not only the birth but also the successful survival of the first hours of the offspring depending on the relations between the newborn and the mother (Konyalı et al., 2004).

It is reported that sheep births have increased at certain times of the day and they prefer silent hours of the day (Ünal \& Akçapınar 1994; Tomar 1979; Alexander 1993). In similar studies, as an increased birth time of different sheep breeds, Karabacak et al. (2012) reported that births were occurred between 10: 01-16: 00 and 04: 01-10: 00 hours; in others study were determined that births were occurred in 16: 00-22: 00 hours (Öztürk (2012)), ) in 04: 00-10: 00 and in 16: 00-22: 00 hours (Özçalık (2010)), in 04: 00-08: 00 hours (Gonyou and Cobb (1986)), in 03: 00-07: 00 hours (Hudgens et al, (1986)), in 13:00-19: 00 and 15: 00-18: 00 hours (Younis and El Gaboury (1978)) and in 01: 0007: 00 hours (Holmes (1976)). Although a large num- 
ber of literature related to many types of research made on sheep behavior exist, the number of research on domestic races in Turkey is quite low.

However, it is known that animal behavior varies according to species and breeds. In particular, the lack of researches related to behaviors of Central Anatolian Merino breed, a substantial part of Turkey's sheep existence, is regarded as a significant shortcoming.

In this study, the effects of sex, type of birth and dam age on the distribution of birth times of Central Anatolian Merino sheep during the day reared at institute conditions were examined.

\section{Material and Methods}

The animal material of the study consisted of Central Anatolian Merino sheep which were raised in Sheep breeding unit of Bahri Dagdas International Agricultural Research Institute. In the study, the effects of dam age (2, 3, 4, 5, 6 and 7), birth type (singleton = 1 , twin $=2)$, lamb sex $($ female $=1$, male $=2$ ) on distribution of births within a day were investigated of 707 animals raised in the farm. Sheep grazing in pasture and stubble started mating in the first week of July and births took place in December and January. Sheep showing signs of delivery (lying-up, bleating, searching for places, etc.) were taken to the previously prepared birth compartment in the barn. During the lambing period, the flock housed in the barn observed every hour during the day and every two hours during the night. Observations were followed until the end of the birth, and date of birth, birth type, lamb sex, and dam age values was recorded. In addition, during the lambing period, the sheep were fed with two meals, morning and evening. Sheep nutrition; high quality dried alfalfa grass as roughage was given and bruised barley wheat, corn grains, sunflower seeds, and soybean pulp as concentrate feed was given by mixing in the feed unit within the institute.

One day (24 hours) was divided into four time periods as 22: 01-04: 00, 04: 01-10: 00, 10: 01-16: 00 and 16: 01-22: 00 to determine at which time lambing occurs more often (Karabacak et al. 2011, Ozturk, 2012). In the statistical analysis of the data, $\chi 2$ analysis was performed by using Minitab (14) package program to determine whether dam age, lamb sex and birth type factor were effective on the distribution of lambing over time periods.

\section{Results and Discussion}

The data of 707 sheep in sheep breeding unit were examined and the data on the distribution of births to different times of the day, the lamb sex, birth type and dam age were evaluated and summarized in the Table1. Accordingly, the highest lamb birth rate $(26.95 \%)$ took place in the third period, followed by $2(25.57 \%), 4$ $(23.93 \%)$ and $1(23.55 \%)$ time periods, respectively. In terms of sex distribution, female ratio was $51.76 \%$ and male ratio was $48.24 \%$, respectively. The highest delivery rate was in 2-years-old mothers with $23.80 \%$ and followed by $4(20.65 \%)$ and 3-years-old mothers $(19.27 \%)$, and the lowest birth rate was of $11.34 \%$ with 6 and 7-years-old mothers. When the type of birth was examined, it was seen that $78.09 \%$ were a singleton and $21.91 \%$ were twins.

As can be seen in Table 2, 23.80\% of the lambs were born from 2 aged, $20.65 \%$ from 4 aged, $19.27 \%$ from 3 aged , $13.60 \%$ from 5 aged, and $11.34 \%$ from 6 and 7 aged sheep. . It was found that $55.03 \%$ of the 2years-old mothers delivered between 10:01 and 22:00 (daytime), $51.63 \%$ of the 3-years-old mothers 22:01 and 10:00 (night), 4-years-old of mothers $56: 67 \%$ 04:01 and 16:00 (day). 53,71\% of the 5-years-old mothers 22:01 and 10:00, 52.22\% of the 6-years-old mothers 4:01 and 16:00 (daytime), $56.67 \%$ of the 7years-old mothers gave birth between 04:01 and 16:00 (daytime). In this study conducted on Central Anatolian Merino sheep, births were found to increase in the morning and evening hours.

It has been reported that the distribution of births to certain time period of the day according to the results obtained in other countries where similar studies are performed have similar results to the results obtained from this study (Alexander 1993, Holmes 1976, Entes 1976, Tomar 1979, Karabacak et al. 2011, Özçalık 2010).

According to the $\chi 2$ test results on the distribution of lamb sex at different times in the study, the distribution of male and female lambs to different times of day was found to be significant $\mathrm{P}<0.05$. As shown in Table 3, 383 of the lambs were born male and 411 were female, and 213 males $(55.61 \%)$ were born between 04:01 and 16:00, 221 females $(53.77 \%)$ between 10:01 and 22:00 when the birth rate was high. It was observed that $170(44.39 \%)$ of the males were born between 16:01 and 04:00 and 190 females (46.23\%) between 22:01 and 10:00 when the birth rate was low. Karabacak et al. (2012) reported in their study on Akkaraman breed sheep that male and female lambs' distribution of births to different hours of the day was insignificant, and $58 \%$ of births occurred in time period between 04: 01-10: 00 and 10: 01-16: 00 coinciding with daytime hours. In this study, it was seen that the time period in which males had the highest birth rate was similar to the study of Karabacak et al. (2015) In Öztürk (2012)'s findings for Akkaraman sheep breed, it was reported that male and female lambs had similar values at the time of birth, but as a result of the analysis, lamb sex had no effect on the delivery time $(\mathrm{P}>0.05)$, and the distribution of male and female lambs to time period was homogeneous. Özçalık (2010) reported in a study conducted on Akkaraman sheep that $54.5 \%$ of males, $52.0 \%$ of females and $53.12 \%$ of all lambs were born between 16:01 and 04:00. 
Uğur and Karabacak / Selcuk J Agr Food Sci, (2019) 33 (3), 227-230

Table 1

Distribution of lamb births at different times of the day, sex, sheep age and lamb rate by birth type (\%)

\begin{tabular}{|c|c|c|c|c|}
\hline Birth Time & $\begin{array}{c}\text { Number of sheep } \\
\mathrm{N}\end{array}$ & $\begin{array}{c}\text { Twins at Birth } \\
\%\end{array}$ & $\begin{array}{c}\text { Lambs } \\
\mathrm{N}\end{array}$ & $\%$ \\
\hline $1(22: 01-04: 00)$ & 168 & 11.31 & 187 & 23.55 \\
\hline $2(04: 01-10: 00)$ & 178 & 14.04 & 203 & 25.57 \\
\hline $3(10: 01-16: 00)$ & 193 & 10.88 & 214 & 26.95 \\
\hline $4(16: 01-22: 00)$ & 168 & 13.10 & 190 & 23.93 \\
\hline Total & 707 & & 794 & \\
\hline \multicolumn{5}{|l|}{ Sex } \\
\hline Male & & 383 & 48.24 & \\
\hline Female & & 411 & 51.76 & \\
\hline Total & & 794 & & \\
\hline \multicolumn{5}{|l|}{ Dam Age } \\
\hline 2 & 172 & 9.88 & 189 & 23.80 \\
\hline 3 & 144 & 6.25 & 153 & 19.27 \\
\hline 4 & 142 & 15.49 & 164 & 20.65 \\
\hline 5 & 95 & 13.68 & 108 & 13.60 \\
\hline 6 & 75 & 20.00 & 90 & 11.34 \\
\hline 7 & 79 & 13.92 & 90 & 11.34 \\
\hline Total & 707 & & 794 & \\
\hline \multicolumn{5}{|l|}{ Birth Type } \\
\hline Single & 620 & 0.00 & 620 & 78.09 \\
\hline Twin & 87 & 100.00 & 174 & 21.91 \\
\hline Total & 707 & & 794 & \\
\hline
\end{tabular}

Table 2

Distribution of birth time according to dam age

\begin{tabular}{|c|c|c|c|c|c|c|c|c|c|}
\hline \multicolumn{10}{|l|}{ Time Period } \\
\hline \multirow{2}{*}{ Dam Age } & \multicolumn{2}{|c|}{ 22:01-04:00 } & \multicolumn{2}{|c|}{ 04:01-10:00 } & \multicolumn{2}{|c|}{ 10:01-16:00 } & \multicolumn{2}{|c|}{ 16:01-22:00 } & \multirow{2}{*}{ Tota } \\
\hline & $\mathrm{n}$ & $\%$ & $\mathrm{n}$ & $\%$ & $\mathrm{n}$ & $\%$ & $\mathrm{n}$ & $\%$ & \\
\hline 2 & 43 & 22.75 & 42 & 22.22 & 57 & 30.16 & 47 & 24.87 & 189 \\
\hline 3 & 48 & 31.37 & 31 & 20.26 & 39 & 25.49 & 35 & 22.88 & 153 \\
\hline 4 & 27 & 16.46 & 48 & 29.27 & 53 & 32.32 & 36 & 21.95 & 164 \\
\hline 5 & 30 & 27.78 & 28 & 25.93 & 21 & 19.44 & 29 & 26.85 & 108 \\
\hline 6 & 19 & 21.11 & 26 & 28.89 & 21 & 23.33 & 24 & 26.67 & 90 \\
\hline 7 & 20 & 22.22 & 28 & 31.11 & 23 & 25.56 & 19 & 21.11 & 90 \\
\hline Total & 187 & & 203 & & 214 & & 190 & & 794 \\
\hline
\end{tabular}

$\chi 2=20.234 ; \mathrm{DF}=15 ; \mathrm{P}-$ Value $=0.163$

Table 3

Distribution of lamb sex according to time periods

\begin{tabular}{|c|c|c|c|c|c|c|c|c|c|}
\hline \multicolumn{10}{|c|}{ Time Period } \\
\hline \multirow{2}{*}{ Sex } & \multicolumn{2}{|c|}{ 22:01-04:00 } & \multicolumn{2}{|c|}{ 04:01-10:00 } & \multicolumn{2}{|c|}{ 10:01-16:00 } & \multicolumn{2}{|c|}{ 16:01-22:00 } & \multirow{2}{*}{ Total } \\
\hline & $\mathrm{n}$ & $\%$ & $\mathrm{n}$ & $\%$ & $\mathrm{n}$ & $\%$ & $\mathrm{n}$ & $\%$ & \\
\hline Male & 96 & 25.07 & 104 & 27.15 & 109 & 28.46 & 74 & 19.32 & 383 \\
\hline Female & 91 & 22.14 & 99 & 24.09 & 105 & 25.55 & 116 & 28.22 & 411 \\
\hline Total & 187 & & 203 & & 214 & & 190 & & 794 \\
\hline
\end{tabular}

According to the $\chi 2$ test results on the distribution of birth type according to different time periods, the distribution of single and twin births to different times of day was not significant at $\mathrm{P}>0.05$ level. As seen in Table 4 , although the birth of singles occurred more during the daylight hours which coincide with 04: 0110: 00. 10: 01-16: 00, and the birth of twin lambs was higher between 04: 01-10: 00 and 16:01-22: 00 which coincide with night hours, it was found insignificant, although it was found to be concentrated in the corresponding. This result is similar to the results reported in similar studies. In a study by Aleksiev (2007), it was reported in the distribution of births to time periods in
Danube sheep that birth type had no significant effect on lambing time distribution. In another study, Younis and El-Gaboury (1978) stated that lamb birth type in Awassi Sheep had no specific effect on the distribution of births. In another study, Romano and Piaggio (1999) reported that the number of kids born did not make a difference in the distribution of the kids to the time periods during the day. In another study, Özçalık (2010) reported that singleton and twin births were more during the time periods between 04: 01-10: 00 and 16: 01-22: 00 , but this was relatively not significant $(\mathrm{p}>0,05)$. 
Table 4

Distribution of birth type according to time periods

\begin{tabular}{|c|c|c|c|c|c|c|c|c|c|}
\hline \multicolumn{10}{|c|}{ Time periods } \\
\hline \multirow{2}{*}{ Birth Type } & \multicolumn{2}{|c|}{ 22:01-04:00 } & \multicolumn{2}{|c|}{ 04:01-10:00 } & \multicolumn{2}{|c|}{ 10:01-16:00 } & \multicolumn{2}{|c|}{$16: 01-22: 00$} & \multirow[t]{2}{*}{ Total } \\
\hline & $\mathrm{n}$ & $\%$ & $\mathrm{n}$ & $\%$ & $\mathrm{n}$ & $\%$ & $\mathrm{n}$ & $\%$ & \\
\hline Single & 149 & 24.03 & 153 & 24.68 & 172 & 27.74 & 146 & 23.55 & 620 \\
\hline Twin & 38 & 21.84 & 50 & 28.74 & 42 & 24.14 & 44 & 25.29 & 174 \\
\hline Total & 187 & & 203 & & 214 & & 190 & & 794 \\
\hline
\end{tabular}

$\chi^{2}=1.979 ; \mathrm{DF}=3 ; \mathrm{P}-$ Value $=0.577$

\section{Result and Conclusion}

As a result, it was found that the effects of the time of births by sheep and the values related to number and rates, the effects of sex on the distribution of birth time according to birth times were significant $(\mathrm{P}<0.05)$, and distribution of birth type according to time periods was insignificant $(\mathrm{P}>0.05)$. While $52.5 \%$ of births $(04$ : 01-10: 00; 10: 01-16: 00) occurred in the daytime hours, $47.5 \%$ (16: 01-22: 00; 22: 01-04: 00) were in the evening and at night. As a result of births, it was determined that the rate of twins was $21.91 \%$. $57 \%$ of male lambs and $50 \%$ of female lambs were born during the daytime. $44 \%$ of males and $50 \%$ of females were born at night. This finding may be useful as an important finding for the owners of Central Anatolian Merino breeding in terms of ease of herd management and increasing productivity. According to the results of this research, it was found that the births were most intense during the day hours, even though the helpless births in sheep changed at every hour of the day. Moreover, it is seen that night births are at a rate that cannot be underestimated. In addition to the precautions taken during daytime births, taking the same precautions for the night births will be important to minimize the lamb deaths that may occur during nighttime births. Monitoring of the animals approaching birth and bringing these animals to special compartments during the birth season will also ensure healthy births.

In this study carried out under the conditions of the research institute, important information in terms of animal behavior in which time period of the Central Anatolian Merino sheep gave birth during the birth season was obtained. During the time of birth when labor period is more intense, if the workers become more active with the sheep in that time period, intervene in difficult births if necessary, and help lambs get their first oral milk, which may prevent the lamb's deaths and provide positive results for the welfare of the enterprise, In this way, it is evident that lambs will increase their livelihood and contribute positively to the profitability of the enterprise. It is very important for the breeders to know the behaviors of the breeds they are raising in order to prevent problems that may occur during the birth season.

\section{References}

Alexander G (1993). The Timing of Birth in Grazing Merino Sheep. Aust, J, Exp, Agric,, 33, 557-560.

Aleksiev Y (2007). Diurnal Distribution of the Time of Parturition in the Danube Fine Wool Breed of Sheep, Bulg, J, Agric, Sci,, 13, 723-728.

Demirören E (2002). Animal Behavior . Ege University, Faculty of Agriculture Publications. 457, p. 278, Bornova, Izmir.

Entes RD (1976). The significance of breeding synchrony in the Wildbeest. East Afric Wildlife J,14, 135-156.

Gonyou HW, Cobb AR (1986). The İnfluence of Time of Feeding on the Time of Parturition in Ewes. Canadian Anim Sci.,66,569-74.

Holmes RJ (1976). Relationship of parturient behavior to reproductive efficiency of Finn sheep. Anim Prod. 36, 253-257.

Hudgens RE, Albright JL, Penningion JA (1986). Influence of Feeding Time and Diet on Time of Parturition in Multiparous Ewes. J. Anim Sci. 63,1036-1040.

Karabacak A, Zülkadir U, Aköz M (2011). Some Reproductive Behavior of Akkaraman Sheep. 7 th National Animal Science Congress, Cukurova University Faculty of Agriculture. Department of Animal Science, Adana.s (144), 12-17.

Karabacak A, Zülkadir U, Aköz M (2012). Some Reproductive Behavior of Akkaraman Sheep.Selçuk Journal of Agricultural and Food Sciences. 26 (4): 55-59.

Konyalı A, Tölü C, Daş G, Gonca C, Savaş T (2004). A research on birth and birth behavior in goats. Journal of Agricultural Sciences, 10 (4), 397-401.

Özçalık O (2010). The distribution of lambing in a day of Akkaraman ewes. Selcuk University Faculty of Science Inst. Master Thesis, KONYA.

Özçalık O, Öztürk A, Keskin İ (2012). The distribution of lambing in a day of Akkaraman ewes. 1st International Iğdır Symposium 113-116.

Öztürk A (2012). The distribution of lambing in a day of Akkaraman ewes. Iğdır Univ. Institute of Science and Technology Bull. 2 (2, Supplement A): 113-116.

Romano JE, Piaggio J (1999). Time of Parturation In Nubian Goats. Departmento de Fisilogia Facultad de Veterinaria, Lasplaces 155011600 Montevideo, Uruguay.

Ünal N, Akçapınar H (1994) Behavior in sheep. Journal of Animal Research. 4 (2), 113-123.

Younis AA, Gaboury LAH (1978). On the Diurnal Variation in the Lambing and Time for Placenta Expulsion in Awasi Ewes. J. Agric. Sci. 91(7), 57- 60.

Tomar SS (1979). Time of parturition in sheep. Ind. J. Anim. Res. 13, 68-70. 